\title{
Salazar y Franco en el panorama internacional: estrategia diplomática y propaganda (1936-1945)
}

\author{
Alberto Pena Rodríguez \\ Profesor Titular. Universidad de Vigo
}

\section{Salazar and Franco in the international scene: diplomatic strategy and propaganda (1936-1945)}

\begin{abstract}
RESUMEN
Este trabajo es una aproximación al estudio de la proyección propagandística

y la estrategia diplomática internacional desarrollada por la dictadura portuguesa y

el Movimiento Nacional franquista para defender, promocionar y consolidar ambos regímenes autoritarios en la Península

Ibérica durante el periodo 1936-1945. El principal argumento de la investigación sostiene que el papel jugado por Salazar y

sus servicios diplomáticos fue muy relevante en la victoria del general Franco en la Guerra Civil española. La prensa y la diplomacia portuguesa prestaron una cobertura propagandística extraordinaria al franquismo. Sin embargo, el estallido de

la Segunda Guerra mundial obligó a

Franco y Salazar a firmar el Pacto de Amistad y No Agresión en 1939 y a crear posteriormente el Bloque Ibérico para garantizar su neutralidad y supervivencia.
\end{abstract}

\section{PALABRAS CLAVE}

Salazar-Franco-Diplomacia-PropagandaPrensa-Guerra.

\section{ABSTRACT}

This research is an approach to study the propagandistic projection and the international diplomatic strategy conducted by the Portuguese dictatorship and the Franco National Movement to defend, to promote and to consolidate both authoritarian regimes in the Iberia Peninsula during the 19361945 period. The main argument of this work holds that the role played by Salazar and his diplomatic services was very relevant for the Franco's victory in the Spanish Civil War. The press and the Portuguese diplomacy lent a extraordinary aid to the Franco regime However, the outbreak of the Second World War II forced to Franco and Salazar to sign the Pact of Friendship and Non Aggresion in 1939 and to create later the Iberian Block to ensure their neutrality and survival.

KEY WORDS

Salazar-Franco-Diplomacy-PropagandaPress-War. 


\section{INTRODUCCIÓN}

En este breve artículo no es posible hacer un abordaje que comprenda todos los aspectos relevantes de este período con una metodología razonablemente rigurosa. Elaborar un relato sobre los diversos acontecimientos y circunstancias políticas que han determinado, de una u otra manera, el devenir de las relaciones ibéricas en un período tan amplio y con tantos elementos de análisis y vericuetos científicos, es un propósito fallido desde su inicio. Por ello, la intención de este trabajo es realizar un enfoque centrado únicamente en los aspectos relacionados con la proyección internacional de la estrategia política y diplomática del salazarismo y el franquismo en el marco de las relaciones ibéricas, con una atención especial al discurso propagandístico por su trascendental importancia en la representación exterior del fascismo ibérico. ${ }^{1}$

Se podría hablar aquí de la ayuda político-ideológica del Estado Novo a Franco, ya estudiada por Iva Delgado ${ }^{2}$ en su pionero libro de 1980; o del apoyo militar de Salazar y del intercambio político entre el franquismo y el salazarismo durante todo el periodo de la guerra fratricida, como hicieron, entre otros, César Oliveira ${ }^{3}$ y José Burgos Madroñero; ${ }^{4}$ o sobre la propaganda del Estado Novo sobre el conflicto a través de la prensa, la radio, la literatura y el cine portugués; ${ }^{5}$ o sobre otros muchos temas, ${ }^{6}$ todos ellos interesantes para construir un retrato completo del proceso histórico de instauración y consolidación del fascismo en la Península Ibérica. Pero se ha optado por el abordaje de la diplomacia y la propaganda a nivel

1 Sobre la propaganda internacional del franquismo y el salazarismo en el período de estudio, pueden verse las siguientes referencias recientes: MORENO CANTANO, Propagandistas y diplomáticos al servicio de Franco (1936-1945), Gijón, Ediciones Trea, 2012; y PENA RODRÍGUEZ, Alberto, «Tudo pela Nação, Nada contra a Nação. Salazar, la creación del Secretariado de Propaganda Nacional y la censura", in Hispania. Revista Española de Historia, 240, vol. LXXII, pp. 177-204.

2 DELGADO, Iva, Portugal e a Guerra Civil de Espanha, Lisboa, Publicações Europa-América, s. d. (1980).

${ }^{3}$ OLIVEIRA, César, Salazar e a Guerra Civil de Espanha, Lisboa, Edições O Jornal, $2^{\underline{a}}$ edição, 1988; idem, Portugal e a Il República de Espanha (1931-1936), Lisboa, Perspectivas e Realidades, s. d. (1985).

${ }_{4}$ BURGOS MADROÑERO, Manuel, «Vinte mil portugueses lutaram na Guerra Civil de Espanha (1936-1939)», in Boletim do Arquivo Histórico Militar, vol. 55, Lisboa, 1987, pp. 87-227.

5 PENA RODRÍGUEZ, Alberto, El gran aliado de Franco. Portugal y la Guerra Civil española: prensa, radio, cine y propaganda, Sada-A Coruña, Ediciós do Castro, 1998; idem, Salazar, a Imprensa e a Guerra Civil de Espanha, Coimbra, MinervaCoimbra, 2007; O Que Parece É. Salazar, Franco e a Propaganda contra a Espanha Democrática, Lisboa, Edições Tinta da China, 2009; Galicia, Franco y Salazar. La emigración gallega en Portugal y el intercambio ideológico entre el franquismo y el salazarismo (19361939), Vigo, Servicio de Publicacións da Universidade, 1999; MATOS, Helena, Salazar. A Propaganda, 1934-1938, Lisboa, Círculo de Leitores-Temas \& Debates, 2010.

${ }^{6}$ DE LA TORRE GÓMEZ, Hipólito, La relación peninsular en la antecámara de la Guerra Civil de España (1936-1939), Mérida, Uned, s. d. (1988); idem, «Las relaciones portuguesas en la Edad Contemporánea", in Reflexiones en torno a España y Portugal, Alicante, Instituto de Cultura Juan Gil Albert, 1993, pp. 33-72. Sobre la configuración ideológica del Estado Novo, véase: TORGAL, Luis Reis, Estados Novos, Estado Novo, Coimbra, Imprensa da Universidade, $2^{\underline{a}}$ edición, 2009. Y sobre la biografía política de Salazar: DE MENESES, Filipe Ribeiro, Salazar. Uma biografía política, Lisboa, Edições Dom Quixote, $4^{a}$ edición, 2010. 
internacional por dos razones fundamentales. Porque es el tema que tiene mejor encaje dentro del número monográfico de la revista sobre franquismo y salazarismo en el exterior; y porque es en el campo de la estrategia de la comunicación pública y las técnicas de propaganda política donde se pueden aportar nuevos datos sobre un objeto de estudio que ha sido estudiado en varios trabajos anteriores, aunque desde una perspectiva más ideológica y política.

Cronológicamente, el objeto de estudio tiene dos contextos claramente diferenciados: la Guerra Civil de España y la Segunda Guerra Mundial. En el primer caso, el texto aborda las campañas diplomáticas y de propaganda realizadas por el Estado Novo portugués en Europa y América para defender los intereses de Franco. El argumento principal del relato transcurre a través de las gestiones diplomáticas y las acciones de propaganda realizadas por el salazarismo para defender los intereses franquistas internacionalmente. De modo particular, se analiza la estrategia seguida por Salazar para proteger los intereses del gobierno de Burgos en el seno de la Sociedad de Naciones y su Comité Internacional de No Intervención, creado para impedir las injerencias exteriores en la guerra. Este es un asunto que fue ya estudiado por autores como Fernando Rosas ${ }^{7}$ o Fernando Schwartz, ${ }^{8}$ pero desde una perspectiva académica distinta, sin el empleo, por ejemplo, de fuentes hemerográficas. La visión que aquí se presenta pretende aportar una nueva visión, enfocada en las técnicas y ardides diplomáticos y propagandísticos empleados por los servicios exteriores del salazarismo para otorgar legitimidad internacional al franquismo.

En el segundo caso, se pretende elaborar un relato coherente sobre cuál fue la reacción de las dictaduras ibéricas a los acontecimientos derivados de la Segunda Guerra Mundial. El objetivo es describir el proceso de la articulación de la estrategia diplomática seguida por el franquismo y el salazarismo para construir un espacio de entendimiento ibérico que preservara sus mutuos intereses en el contexto internacional del conflicto. Las relaciones de Franco y Salazar con las potencias europeas en combate, fundamentalmente con Alemania y Gran Bretaña, y las reacciones políticas de ambos Estados ante los cambios sucedidos durante este complejo período de la historia peninsular, con la firma del Tratado de Amistad y No Agresión (1939) y los posteriores acuerdos diplomáticos que desembocaron en la creación del Bloque Ibérico y sus consecuencias, son otro de los elementos principales del objeto de estudio.

El texto se nutre de fuentes documentales y hemerográficas de archivos portugueses y también de la bibliografía especializada en esta materia. La estructura

7 ROSAS, Fernando, «A Guerra Civil de Espanha na Sociedade das Nações. Salazar, Ministro de Negócios Estrangeiros de Burgos", in revista História, 82, Lisboa, 1985, pp. 33-53. Véase también, más reciente, el libro de Luis Soares de Oliveira, Guerra Civil de España: intervenção e não intervenção europeia, Lisboa, Prefácio, 2009.

${ }^{8}$ SCHWARTZ, Fernando, La internacionalización de la Guerra Civil española (julio de 1936-marzo de 1937), Madrid, Ediciones Ariel, 1971. 
de sus contenidos está dividida en 5 partes fundamentales, además de una breve introducción: los dos primeros epígrafes abordan el papel de Portugal en el Comité de Londres y las campañas de propaganda realizadas en Europa por la diplomacia salazarista para proteger los intereses del movimiento militar golpista en España; el tercero se adentra en la descripción de algunos aspectos relacionados con la colaboración entre la diplomacia lusa y franquista en América para buscar apoyos políticos y proyectar internacionalmente una imagen benevolente del llamado Movimiento Nacional español; los dos siguientes apartados abordan las relaciones diplomáticas ibéricas con la guerra continental como telón de fondo; y finalmente se aportan unas sencillas conclusiones con los argumentos principales del artículo.

\section{PORTUGAL, LA POLÍTICA DE NO INTERVENCIÓN Y EUROPA: DIPLOMACIA Y OPINIÓN PÚBLICA}

La dictadura de Salazar, utilizó todos los recursos diplomáticos para favorecer los intereses del general Franco dentro del Comité Internacional de No Intervención (designado como Comité de Londres porque sus reuniones se celebraban en la capital británica, como es sabido) y otros foros políticos internacionales. El Comité de Londres fue una organización creada a propuesta de Francia e Inglaterra al inicio de la guerra para impedir la internacionalización del conflicto fratricida español y su deriva hacia una guerra mundial en un momento de máxima tensión entre las democracias y las dictaduras europeas. Pero debido a los impedimentos puestos por Portugal, que se resistió hasta el último momento a adherirse formalmente y respetar los compromisos del comité londinense, los objetivos fijados por los 27 países integrantes del mismo no se cumplieron. De hecho, Alemania e Italia, que firmaron el Pacto de No Intervención el 8 de agosto de 1936, intervinieron al lado del bando rebelde, y la URSS prestó ayuda al gobierno republicano, como ya se ha relatado en decenas de estudios. ${ }^{9}$ La sistemática obstaculización portuguesa a la pretendida fiscalización de sus fronteras nacionales y peninsulares por parte del Comité de Londres permitió a Franco contar durante toda la guerra con Portugal como segura retaguardia, a través de la que recibió abundante armamento y combatientes extranjeros, entre ellos cerca de 8.000 soldados portugueses, que lucharon integrados en diferentes contingentes militares del ejército sublevado. ${ }^{10}$

La defensa salazarista del proyecto político franquista provocó enfrentamientos diplomáticos y políticos de Portugal con otros países, que acusaban a Salazar de estar al servicio de la causa insurgente contra el gobierno de la IIa República española. En este contexto, la prensa portuguesa también participó en el tablero diplomático internacional a favor del golpe de Estado en España, al funcionar como legitima-

\footnotetext{
9 Cf.: SCHWARTZ, Fernando, La internacionalización..., Op. Cit.
}

10 OLIVEIRA, César, Salazar..., p. 232. 
dora de las políticas del gobierno luso y actuar en defensa de los intereses franquistas en el exterior, convirtiéndose en una eficaz plataforma mediática desde la que se promovieron campañas de comunicación que mejoraron la imagen externa de Franco y perjudicaron los intereses del régimen democrático español. ${ }^{11}$ Los periódicos portugueses desmintieron muchas informaciones negativas para la imagen internacional del Movimiento Nacional golpista y atacaron a la prensa de otros países que criticaban el comportamiento de los diplomáticos portugueses (cuya cartera de Negocios Extranjeros ocupó el propio Salazar a partir del 6 de noviembre de 1936 y no abandonó hasta el 4 de febrero de 1947) mientras aplaudían las gestiones diplomáticas de su gobierno nacional durante el proceso de ingreso en el Comité de Londres. El Comité debía ejercer la fiscalización de las fronteras y puertos, procurar la retirada de los voluntarios extranjeros en ambos bandos y estudiar los posibles proyectos de mediación. Al principio, Portugal utilizó una planificada estrategia dilatoria para no participar en esta comisión internacional, de la que no formaría parte hasta el 29 de septiembre de 1936, después de las intensas presiones de los gobiernos francés e inglés y muchos medios de comunicación europeos.

La principal razón aducida por el gobierno del Estado Novo para ausentarse era el temor a que el Comité pudiese vulnerar su soberanía nacional, mostrándose extremamente celoso en las competencias del organismo. Tanto antes como después del ingreso, Salazar puso en práctica una premeditada estrategia diplomática y propagandística, en colaboración con el gobierno de Burgos, para hacer prevalecer los intereses de los insurgentes en Europa y en América. La abundante documentación encontrada en los archivos del gobierno portugués demuestra la connivencia entre Franco y Salazar en este aspecto. Son innumerables los telegramas intercambiados entre el dictador portugués y sus representantes en diferentes partes del mundo en el sentido de favorecer la propaganda de los facciosos españoles, aconsejando la publicación de determinadas notas oficiales del gobierno portugués dependiendo de las circunstancias políticas de cada situación. ${ }^{12}$ Junto a la ofensiva diplomática, los diarios lusos no cesaron de destacar la valentía y la coherencia de la política exterior de su gobierno, mientras se ejercía la censura sobre los telegramas enviados por la agencia Havas sobre todo lo relacionado con el Comité de Londres. ${ }^{13}$ El 19 de septiembre de 1936, el secretario general del Ministerio de Asuntos Exteriores de Portugal, Teixeira de Sampayo, resumió en una lapidaria y acertada frase la posición soberana del gobierno portugués respecto a la aplicación de la política de no intervención y el papel clave de su diplomacia en el desenlace de la guerra española: «Portugal é o juiz do momento». ${ }^{14}$

\footnotetext{
11 PENA ROdRÍGUEZ, Alberto, O Que Parece É..., Op. Cit.

12 Arquivo Oliveira Salazar/Arquivos Nacionais Torre do Tombo (AOS/ANTT), CO/NE-9B, carpeta 1. «Não intervenção. Actividade do Comité de Londres».

13 AOS/ANTT, CO/NE-9, carpeta 1, 16 $6^{\text {a }}$ subdivisión, hojas no 110-114. «Não intervenção (1936-1938). Telegramas diversos de la agencia Havas cortados por la Direcção dos Serviços de Censura.

${ }_{14}$ AOS/ANTT, CO/NE-9B, carpeta 1, 69ª subdivisión, hoja nํ209. Telegrama nº 57 del Secretário-Geral del Ministério de Negócios Estrangeiros al ministro de Negócios Estrangeiros en Ginebra, 19/09/1936.
} 
Las maniobras dilatorias de Salazar suscitaron un aluvión de críticas por parte de la prensa de los países democráticos europeos y de sus respectivos gobiernos, que querían ver cuanto antes a Portugal integrado dentro del Comité de Londres para evitar suspicacias y malentendidos; y para que su rebeldía no fuese objeto de divisiones y enfrentamientos que podían frustrar la propuesta anglo-francesa de no intervención. Además, la URSS y algunos de los periódicos europeos más influyentes, como el News Chronicle, el Times, o Le Soir, denunciaron la existencia de tráfico de armas entre Portugal y el bando rebelde español. ${ }^{15}$ Estas informaciones movilizaron a la opinión pública inglesa, que puso en un aprieto a la diplomacia portuguesa en Londres, ya que el 30 de agosto se organizó una manifestación contra la intervención lusa en la Guerra Civil española que desembocó en el edificio de la embajada y cuyo lema era «Stop aid to the Spanish fascists». ${ }^{16}$ El portavoz de los manifestantes, John Mahor, entregó al embajador de Portugal una carta en la que, de acuerdo con los hechos relatados por la prensa inglesa, se pedía el fin de la ayuda portuguesa a los rebeldes españoles:

«We are requested by the mass demostration held tonight in Hyde Park to bring to your attention the serious concern being felt by great numbers of London citizens at the attitude of the Portuguese authorities who are reported to be favouring the Fascist rebels in Spain in the attack on the constitutional and democratically elected government of that country. It is reported in the press of this country that aid is being given to rebels from Portuguese territory in the following ways:

1. Arms and munitions are being supplied across Portuguese territory;

2. Rebel officers are allowed to discuss the affairs of the rebels and to send instructions from a base on Portuguese territory;

3. Rebel airplanes are allowed to fly across Portugal, to land and take off again;

4. Military and civilian fugitives loyal to the Spanish Government who have crossed the frontier have been handed over by the frontier guards to the rebel forces instead of being interned (...). ${ }^{17}$

El gobierno luso se mantuvo firme hasta el límite de lo posible. Monteiro dio instrucciones a todos sus diplomáticos para que hiciesen público que el gobierno portugués consideraba el Comité de Londres «(...) como um organismo destinado a violar o acordo de não-intervenção, favorecendo os Governos de Madrid, Barce-

${ }^{15}$ Dez Anos de Política Externa (1936-1947). A Nação Portuguesa e a Segunda Guerra mundial, Lisboa, Imprensa Nacional, vol. 4, 1964, documento $\mathrm{n}^{\circ}$ 226, p. 201. Telegrama $\mathrm{n}^{\circ} 107$ del encargado de Negócios de Portugal en Londres al ministro de Negócios Estrangeiros, 26/08/1936.

16 Dez Anos de Política Externa..., Op. Cit., documento no 249, p. 219. Telegrama no 115 del encargado de Negócios de Portugal en Londres al ministro de Negócios Estrangeiros, 31/08/1936.

17 Idem, documento n을 246, p. 215. «Texto da carta entregue ao porteiro da embaixada de Portugal en Londres, em 31 de agosto de 1936, por três representantes de uma manifestação contra a pretensa intervenção portuguesa na guerra da libertação de Espanha», 30/08/1936. 
Iona e Valencia contra os nacionalistas (...)». ${ }^{18}$ La revuelta de los marineros portugueses contra su gobierno el 9 de septiembre de 1936 fue instrumentalizada propagandísticamente y sirvió de nueva excusa para insistir en los contagios del comunismo español en Portugal y reivindicar, una vez más, su especialísima y delicada situación a través de una nota oficial muy elogiada por la prensa salazarista. ${ }^{19}$ Mientras se sucedían las presiones, Teixeira de Sampaio coordinó con los agentes rebeldes Súñer Erice y Mariano Amoedo la elaboración de comunicados y notas oficiales para transmitir a la prensa internacional los motivos de la intransigente postura portuguesa. ${ }^{20}$ Durante la celebración de la Asamblea de la Sociedad de Naciones (SDN), el 25 de septiembre de 1936 (en la que por vez primera se iba a debatir el asunto español), el ministro Armindo Monteiro se entrevistó en Ginebra con sus homólogos inglés y francés, Anthony Eden e Yvon Delbos, respectivamente, que volvieron a recordarle la perentoria necesidad de la adhesión portuguesa al Comité de Londres. Monteiro pidió entonces por telegrama a Salazar que se iniciase una campaña de propaganda en la prensa francesa para fortalecer la posición lusa, ya que presentía que Francia iba a llevar a cabo alguna acción contra Portugal dentro de la SDN tras los contactos en Ginebra de Delbos con el ministro de Exteriores de Madrid, Julio Álvarez del Vayo:

«Segundo minhas informações Ministro dos Negócios Estrangeiros Espanha teve ontem conferência com Ministro Negócios Estrangeiros França àcerca atitude Portugal apresentando queixa contra nós. Ministro Negócios Estrangeiros França teve sobre mesmo assunto conferência com Lord Granbourne. Isto me leva a crer que França prepara qualquer golpe contra Portugal. Julgo necessário pra deminuir força Govêrno neste assunto iniciar alguns jornais franceses mais simpatisantes campanha destinada explicar nossa situação e razões que nos assistem. Salvo pequeno artigo ou noticia que Legação tem conseguido inserir sobretudo na Liberté pode dizer-se quasi toda a Imprensa francesa nos é desfavorável. Ministério não tem meios financeiros fazer despesa necessária. Mas Secretariado Propaganda deve ter, visto verbas propaganda Ministério terem sido transferidas para seu orçamento. Peço atenção S. Ex ${ }^{\mathrm{a}}$ Presidente do Conselho este assunto. Julgo urgentissimo que com insistência nossos pontos de vista sejam expostos França. Querendo S. Ex ${ }^{\underline{a}}$ o presidente do Conselho é claro que Ministério tambem pode ocupar-se esse assunto. Preciso lembrar que Italia venceu SDN sobretudo com imprensa francesa.» 21

18 Idem, documento nำ 267, p. 236. Telegrama nํ51 del ministro de Negócios Estrangeiros al embajador de Portugal en Berlín, 05/09/1936.

19 Idem, documento nº 290, pp. 255-258. «Nota oficiosa da Presidência do Conselho», 09/09/1936. Véanse también los siguientes artículos de los diarios portugueses: «Lição dos Factos. Nota oficiosa», in Diário da Manhã, no 1939, 10/09/1936, p. 1; «Providências oportunas», in idem, nº 1940, 11/09/1936, p. 1; «Ecos da marujada marxista», in idem, nº 1940, 11/09/1936, p. 8; «Manobra comunista e maçónica contra Portugal. A grande imprensa europeia faz justiça ao nosso Pais» (noticia firmada por el gobierno), in idem, no 1941, 12/09/1936, p. 1; «Reacção sentimental», in idem, no 1942, 13/09/1936, p. 1; «Roidinhos de inveja. Desafazendo boatos e atoardaa», in Diário de Notícias, no 25.370, 20/09/1936, p. 1; «Não afrouxar!», in $A$ Voz, no 3454, 02/10/1936, p. 1, entre otros.

20 AOS/ANTT, CO/NE-9B, carpeta 1, 69 subdivisión, hoja n 209. Telegrama n 57 del Secretário-Geral al ministro de Negócios Estrangeiros en Ginebra, 19/09/1936.

21 AOS/ANTT, CO/NE-9B, carpeta 1, 69 subdivisión. 
Armindo Monteiro comenzó su campaña de propaganda contra la II República española en Ginebra, concediendo una entrevista al diario Journal de Genéve, a través de la que pretendía demostrar la buena voluntad de su gobierno en la negativa a hacerse representar en el Comité de Londres, alegando no tener suficiente información sobre sus funciones: «O meu pais tem sempre dado provas dum grande espirito de colaboração em Europa: Genebra sabe-o bem. Não queremos interromper essas tradições. Mas o momento é muito grave para que aceitemos de ánimo leve entrar no desconhecido: é indispensável, pelo menos, que saibamos para onde nos querem levar e como" ${ }^{22}$

La prensa portuguesa acompañó la política salazarista de contención frente a las críticas exteriores acusando al gobierno francés de ayudar militarmente al bando leal. ${ }^{23}$ El 15 de septiembre de 1936, el Diário da Manhã (órgano del partido único de régimen, la União Nacional), tras calificar de «idiotices» las denuncias europeas contra Portugal por su engañosa política de no intervención, responde citando varias cabeceras galas que se alineaban con el Estado Novo como Le Journal, Le Figaro, L'Echo de Paris y L'Ami du Peuple. ${ }^{24}$ Periódicos que, según el diario dirigido por Pestana dos Reis, "(...) fustiga os fariseus da extrema esquerda que pretendem convencer o Mundo de que os portugueses querem libertar-se do jugo da Ditadura de Salazar». ${ }^{25}$ El 25 de septiembre, la misma cabecera lusa se hace eco de unas supuestas revelaciones del ultraconservador Action Française sobre el envío a Madrid de armamento autorizado por el primer ministro galo, Leon Blum. ${ }^{26}$ En la campaña propagandística contra Francia participó también el Rádio Club Português, que emitió hacia Europa sus exclusivas noticias sobre la venta de armamento francés a los leales. ${ }^{27}$

Portugal reaccionó a las críticas de los medios de comunicación internacionales y de otros gobiernos europeos emitiendo comunicados públicos (en los que el gobierno exponía sus puntos de vista sobre el conflicto español) que obtuvieron una amplia cobertura por parte de la prensa portuguesa y europea. Salazar emite públicamente una agria «nota oficiosa» el 22 de septiembre como reacción oficial del Estado Novo contra las críticas a su política de no intervención. En el comunicado el gobierno portugués hace una interpretación maniquea de los acontecimientos de España: el dictador luso legitima la rebelión del ejército español porque, según él, no luchaba contra la democracia parlamentaria, sino contra el "comunismo" internacional. ${ }^{28}$ Salazar insiste en que Portugal cumplió religiosamente con su deber y no faltó nunca a sus compromisos, editando y respetando el

22 Diário da Manhã, no 1956, 27/09/1936, p. 1.

23 Diário de Notícias, no 25.342, 23/08/1936, p. 1; idem, no 25362, 12/11/1936, p. 1; O Século, no $19537,05708 / 1936$, p. 1, entre otros números.

24 Diário da Manhã, no 1944, 15/09/1936, p. 1.

25 Ibídem.

26 Idem, no 1954, 25/09/1936, p. 5.

27 O Século, no 19.568, 05/09/1936, p. 5.

28 Portugal y la Guerra Civil de España. Lisboa: Edições do SPN, pp. 33-34. 
decreto $n^{\circ}$ 26935, del 27 de agosto, en virtud del cual se prohibía la exportación de armas a España. ${ }^{29} \mathrm{Y}$ añade en la misma nota que algunas cancillerías europeas se limitaban a hacer política siguiendo las consignas interesadas de «(..) informaciones anónimas de emisoras desconocidas, las deficientes noticias de las agencias y las pasiones de cierta Prensa (...) ${ }^{30}{ }^{30}$ que atacaban a su gobierno deseando que Portugal cambiase de régimen para hacer «(...) vulnerable la retaguardia de todo el ejército español»». ${ }^{31}$ Estos comentarios refuerzan el argumento fundamental de la propaganda del Estado Novo con el que pretendía justificar su recelo frente a Madrid, basado en el «iberismo» anexionista del comunismo español (sic):

«(...) Los que han seguido sin apasionamiento el drama peninsular, los que no han olvidado la historia de hace décadas, de hace años y de hace días, los que se acuerdan de las ambiciones alguna vez manifestadas del plan ibérico del comunismo, de la claridad, alias (sic) muy de agradecer con que muchas veces ha sido defendido en la Prensa el derecho de intervención en Portugal, nos hacen justicia de creer que los temores no son románticos, ni tampoco que por capricho levantamos dificultades a nadie: simplemente no desistimos de que sea respetada nuestra tranquilidad ni podemos transigir en lo necesario a la defensa de la vida y libertad de nuestro pueblo (...).»32

Para demostrar que el pueblo portugués apoyaba unánimemente a Salazar, al día siguiente de la publicación de esta comunicación oficial, el Diário da Manhã informa que en su lugar de residencia se recibieron «(...) milhares de telegramas de felicitações de todos os pontos do Pais e na maioria dos quais transparece 0 fervor patriótico da hora que passa». ${ }^{33}$ Tras este episodio de la batalla diplomática librada entre Portugal y las potencias democráticas, el Estado Novo decide participar en el Comité de Londres el 29 de septiembre de 1936. ${ }^{34}$ Sin embargo, la participación portuguesa coincide con la ofensiva diplomática soviética a favor de Madrid y se enrarece repentinamente el clima de cordialidad del comité internacional debido a un cruce de acusaciones mutuas entre Lisboa y Moscú. El gobierno portugués adopta inicialmente una posición de cautela, pero el representante soviético, que quería eludir un enfrentamiento directo con Alemania e Italia, elige a Portugal como chivo expiatorio. Las discusiones se precipitan hacia el enfrentamiento polarizado y estridente entre ambos países. La prensa portuguesa, al igual que había hecho con Francia, la emprendió contra la URSS con inusitada agresividad. El Diário de Lisboa la acusa el 10 de octubre de ser el causante de la guerra fratricida española:

${ }^{29}$ Idem, p. 36. El decreto puede leerse en Dez Anos de Política Externa..., Op. Cit., documento ํㅡㄴ 231 , p. 206.

30 Ibídem.

31 Ibídem, p. 39.

32 Ibídem, pp. 39-40.

33 Diário da Manhã, no 1952, 23/09/1936, p. 1.

34 Dez Anos de Política Externa..., Op. Cit., documento no 426, pp. 371-372. telegrama no 165 del encargado de Negócios de Portugal en Londres al ministro de Negócios Estrangeiros, 29/09/1936. 
«(...) A Russia, veladamente, e o komitern, declaradamente, propõem-se desencadear a revolução comunista nas cinco partes do mundo. Todo o pacto de não-intervenção Ihe contraria a liberdade de movimentos. Os seus agentes ou sub-agentes, com máscara ou sem mascara, percorrem as cidades e traspõem as fronteiras mais distantes. A Espanha era-lhe particularmente simpática, visto estar predestinada para a proxima aurora vermelha (...).» ${ }^{35}$

La diplomacia portuguesa actúa entonces con una peculiar firmeza frente a los ataques de Moscú, que intenta sucesivas veces convencer a los otros miembros del comité de las hipotéticas vulneraciones del acuerdo de no intervención. Mientras tanto, el Diário da Manhã prosigue su goteo constante de informaciones sobre la participación rusa en la guerra y magnifica la resistencia portuguesa a la fiscalización de sus puertos frente a la «insolência soviética» ${ }^{36}$ :

«Justifica-se, porém o ódio russo - disso nos vanagloriamos. Contra a muralha que há mais de um século deteve ás hostes napoleónicas, até então bafejadas pela vitória - contra Portugal! - veio quebrar-se agora a onda bolchevista. Aqui não se passa!. O povo português, sempre reservado para altos destinos, quando se trata de propagar ou salvar a Civilização ocidental, a Civilização cristã, estava, providencialmente, preparado para ocupar o seu pôsto, conduzido por um Chefe (...). É êste um dos mais belos títulos de glória dêste pequeno grande Povo que, na hora propria e por suas virtudes raras, só conhece o triunfo em prol de todos.»37

La prensa salazarista reafirma así su discurso patriótico en esta dura polémica en la que el gobierno portugués decidió tomar el «caminho da honra», ${ }^{38}$ cumpliendo todos los preceptos legales del comité, según el Diário da Manhã, mientras la URSS sólo buscaba «(...) arranjar motivos com que justificar as suas faltas e pretextos para desligar-se do acôrdo de neutralidade (...)». ${ }^{39}$ El conflicto luso-soviético en el seno del organismo supranacional es convertido por la propaganda salazarista en un asunto de la máxima preocupación, que afectaba a la soberanía e incluso a la supervivencia de Portugal como potencia colonial. El Diário de Notícias no tenía dudas sobre el trasfondo del problema: «(...) o problema é este: ser ou não ser português, manter ou renegar o vínculo secular que prende um certo número de famílias irmanadas pela lingua, pelos costumes e pela história (...)».40

Los momentos más delicados para la diplomacia portuguesa dentro del Comité de Londres se sucedieron a partir de la propuesta de fiscalización de las fronteras españolas y la cuestión de la retirada de los voluntarios extranjeros alistados en ambos bandos. El 16 de diciembre de 1936, a través de un nuevo comunicado de prensa, Salazar se niega a permitir una mediación, como sugerían Francia e

\footnotetext{
35 Diário de Lisboa, № 4992, 10/10/1936, p. 1.

36 Diário da Manhã, no 1984, 26/1071936, p. 1.

37 Idem, no $1982,24 / 10 / 1936$, p. 1.

38 Idem, no $1974,16 / 10 / 1936$, p. 1.

39 Idem, no 1987, 29/10/1936, p. 1.

40 Diário de Notícias, no 25.422, 12/11/1936, p. 1.
} 
Inglaterra, arguyendo que era una idea que ponía el peligro la «civilización occidental». ${ }^{41}$

Atrincherado en esta propaganda, el gobierno portugués se opuso tajantemente a cualquier tipo de fiscalización; y menos a que los barcos rusos patrullasen sus aguas. Estas nuevas afrentas lusas contra el comité volvieron a colocar a Portugal en el primer plano de la actualidad informativa mundial a finales de 1936. Los diarios portugueses utilizaron la actitud de su gobierno para reivindicar el protagonismo político de Portugal en el escenario internacional. ${ }^{42}$ La intransigencia diplomática de Portugal dignificó y engrandeció su posición en el mundo, según repetía machaconamente la propaganda de los editoriales de las cabeceras lusas, tal y como se puede leer en O Século el 20 de febrero de 1937:

«(...) Vendo-se mais uma vez dignificado e fortalecido perante o mundo, o povo português não pode deixar de exultar, por em momentos de tantas dificuladades como aquelas que a erupção comunista espanhola nos criou, ter encontrado a zelar pela sua soberania e pela sua tranquilidade um homem excepcional, perante cuja honradez, patriotismo e clarividência não tem remédio senão curvar-se os que com ele tratam atravês dos meandros das chancelerias. Essa glória ninguém a pode recusar o chefe do Govêrno português. Que lea sirva de escudo a quantos, olhando para nós, dão a impressão de ter inveja de nos vêr serenos, confiados e felizes!.» ${ }^{43}$

El Estado Novo sale reforzado en la refriega diplomática frente al enemigo soviético, mientras Francia e Inglaterra son ridiculizadas sin compasión por ceder ante la URSS, cuyos navíos participaron en la vigilancia de las costas de España para someterla al embargo de armas.

Sin embargo, la publicación en febrero de 1937 del libro Portugal Now, del periodista inglés del News Chronicle Ralph Fox, en el que se denuncia el descarado apoyo de la dictadura portuguesa a los insurgentes españoles, ${ }^{44}$ causa preocupación al ya embajador en Inglaterra, Armindo Monteiro, que envía un ejemplar a Salazar y le advierte por telegrama que el Daily Herlad está haciendo una amplia promoción de la obra. ${ }^{45}$ La presión internacional obliga finalmente al gobierno salazarista a aceptar la fiscalización de sus fronteras, pero sólo se muestra dispuesta a que ésta la lleven a cabo observadores ingleses, tal y como lo explica su gobierno a la opinión pública en la nota de prensa publicada el 20 de febrero de $1937 .{ }^{46}$ Los observadores llegaron finalmente a Lisboa el 9 de marzo a

41 Portugal e a Guerra Civil de Espanha, Op. Cit., p. 85.

42 HALPERN PEREIRA, Miriam, Política y economía. Portugal en los siglos XIX y XX, Barcelona, Ariel, 1984.

43 O Século, no 19.730, 20/02/1937, p. 1.

44 FOX, Ralph, Portugal Now, London, Lawrence \& Wishart, 1937. Edición en español: Portugal, 1936, Madrid-Barcelona, Ediciones Europa-América, s. d. (1937).

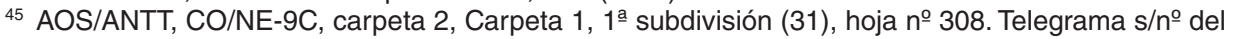
embajador de Portugal en Londres al ministro de Negócios Estrangeiros, 12/02/1937.

46 Portugal y la Guerra Civil de España, op. cit., pp. 97-99. 
bordo del buque Almanzora. ${ }^{47}$ Justo el día anterior, Salazar difunde otra «nota oficiosa" para rebatir un telegrama ofensivo de la agencia United Press, en la que se dice que Portugal había retirado sus objecciones contra el control de sus costas por barcos rusos. ${ }^{48}$ «(...) No siendo cierta esta noticia el gobierno apresúrase a desmentirla (...)", señala el escrito oficial. Entretanto, la prensa habla de la inutilidad de una fiscalización "tardía», cuando ya los rusos y franceses, se decía, habían proporcionado el armamento suficiente a los leales para una resistencia por tiempo indefinido. ${ }^{49}$

\section{LA ACCIÓN DIPLOMÁTICA DE SALAZAR A FAVOR DE FRANCO: PRENSA Y PROPAGANDA}

A principios de abril de 1937, Armindo Monteiro intercambia impresiones con el embajador italiano en Inglaterra, que le comunica la necesidad urgente de incrementar la propaganda franquista en aquel país para contrarrestar la influencia rusa. «(...) Para corrigir as notícias do (representante) russo (...)», le decía el diplomático italiano a Monteiro, «(...) tenho tentado, uma vez ou outra, fazer passar nos «national papers» notícias favoráveis ao Franco. Impossível. Imagine que até jornais que durante o conflicto com a Abisinia me ajudaram, agora se me fecham completamente. Estão dominados pelo receio da influência italiana em Espanha depois de terminada a guerra e ninguém os arranca dessa posição (...) ${ }^{50} \mathrm{El} 5$ de mayo el embajador luso le expresa al dictador portugués su irritación por la campaña de propaganda contra los gobiernos franquista, italiano y alemán debido al veto de Roma y Berlín a aplicar las medidas de prohibición de bombardeos en ciudades abiertas:

«Imprensa esta manhã grandes títulos acusa Italia Alemanha sobretudo esta última se oporem a que uma resolução fosse tomada àcêrca da questão bombardeamento cidades abertas. Falsificação factos evidente. Responsabilidade factos pertence como sempre russos que infelizmente sem oposição Governos manejam esta imprensa. Natural que alemaes levantem caso reunião sub-comité. Julgo poder sugerir como unico remedio eficaz que se tornem publicas nossas reunioes o que certamente francês russo não querem por lhes ser tirada arma intrigas que manejam maravilhosamente. Podia tambem sugerir que a cada repre-

\footnotetext{
47 Los observadores británicos que participaron en la fiscalización de las fronteras portuguesas eran: el capitán Malcom MacDonald (jefe de la misión), Lonsdalle Parsus, Wilfreid Sydney Booth, William D. Giel, Charles Henry Danners, Friederich Cullen, Albert Eduard Almeida y Henry Newbof Lester. Casi todos hablaban portugués, pues estuvieron en Brasil y Oporto trabajando en diferentes empresas. En concreto, MacDonald estuvo trabajando hasta julio de 1936 como director de la Vacuum Oil Company. Su misión era observar y remitir los informes pertinentes al embajador de Inglaterra, y éste se encargaba de enviarlos al Comité de No Intervención. La fiscalización no se puso en marcha hasta el 21 de abril de 1937. Cf.: O Século, no 19.748, 10/03/1937, pp. 1 y 2.

48 Portugal y la Guerra Civil de España, Op. Cit., pp. 101-112.

49 O Século, no 19.793, 24/04/1937, p. 1.

50 AOS/ANTT, CO/NE-9D, carpeta 1, 9a subdivisión, hojas $n^{\circ}$ 36-40. Oficio s/no del embajador de Portugal en Londres al ministro de Negócios Estrangeiros, 08/04/1937.
} 
sentante fosse dada liberdade fornecer seu proprio relato imprensa. Fomos varias vezes victimas das intrigas russo (sic) creio chegou momento clarear situação dado que desta vez se não meteram connosco.»51

Por su parte, Salazar envía a Monteiro el 9 de mayo un telegrama en el que le dice que hay que impedir por todos los medios que la URSS emita libremente sus comunicados sobre los debates del Comité de Londres, porque su influencia en la prensa inglesa y francesa es mayor que la de Portugal. Esta situación provoca una desventaja propagandística muy grande. «(...) Revelação factos passados Comité e subcomité e sua deturpação por meio noticias imprensa ordens Russia muito grave pela influência que isso pode ter para desorientar opinião pública diferentes paises (...)». ${ }^{52}$ Salazar ordena actuar de forma «nítida e firme» en este asunto, plantando batalla en el sentido de conseguir que el Comité de Londres emita un comunicado conjunto de todos los miembros para evitar los comentarios especulativos. «(...) É indispensável que haja um relato oficial aprovado por todos do que se passe quando se queira informar público pela imprensa (...) ${ }^{53}$ El gobernante luso indica que, en caso de no ser atendida su demanda, comunique a la dirección de la comisión que Portugal «(...) se verá obrigado a não colaborar mais nos trabalhos do Comité, pois não está disposto a contribuir por atitude passiva para desorientação da opinião dos diferentes paises com fins diametralmente opostos àqueles para que se diz ter sido feito acordo não intervenção (...) ».54 El 25 de mayo, Salazar transmite por telegrama a Monteiro más instrucciones, esta vez del gobierno de Burgos, en el sentido de impedir la aprobación de otra propuesta que perjudicaría al bando rebelde:

«Representação Estado Espanhol informa por ordem seu Governo que o subcomité assuntos financeiros projecta apresentar proposta Comité não-intervenção de contrôle fundos que em nome espanhois figurem bancos estrangeiros. Govêrno nacionalista pede que representante de Portugal Londres se oponha aprovação proposta por dificultar recentes disposiçoes sobre moeda estrageira decretadas Governo general Franco e em geral manejo fundos no estrangeiro. Proposta não prejudica Governo Valencia que dispoe importante quantidade divisas em bancos estrangeiros e em nome de estrageiros.»55

Gracias al gobierno del Estado Novo la fiscalización de la frontera acabó siendo un fracaso. Pero, en julio de 1937, el Foreign Office insiste en la puesta en marcha del plan de retirada de los voluntarios. El 6 de julio, el embajador portugués en Londres solicita la aprobación de Salazar de las directrices marcadas por el Duque

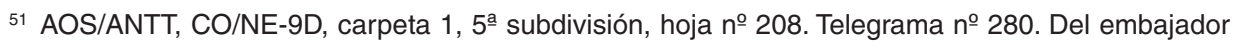
de Portugal en Londres al ministro de Negócios Estrangeiros, 05/05/1937.

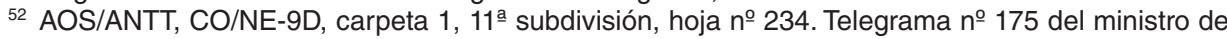
Negócios Estrangeiros a la embajada en Londres, 09/05/1937.

53 Ibídem.

54 Ibídem.

55 AOS/ANTT, CO/NE-9D, carpeta 1, 37ª subdivisión, hoja $n^{\circ}=331$. Telegrama $n^{\circ} 200$ del ministro de Negócios Estrangeiros al embajador de Portugal en Londres, 25/05/1937. 
de Alba sobre la defensa de los intereses de Franco en este caso. ${ }^{56}$ Consciente del desgaste que estaba sufriendo la diplomacia portuguesa en estas lides, Armindo Monteiro recomienda al dictador portugués la publicación de artículos en la prensa de su país para mitigar las «(...) populares ameaças contra Portugal (...)»57 en la prensa londinense. Según el embajador luso, la propaganda fortalecería su posición en la alianza luso-británica para hacer cambiar la política peninsular inglesa a favor de los facciosos:

«(...) Talvez tivesse chegado a ocasião fazer publicar aí artigos cautelosos mas mostrando que na aliança somos não elemento passivo como aqui toda a gente acredita mas elemento que tem na sua mão interesse fundamental para Inglaterra (...). Julgo que conviria fazer sentir mais uma vez Inglaterra sua politica não tem tido conta perigos interesses especiais Portugal e que por isso não é justo esperar que a acompanhemos olhos fechados na sua politica peninsular (...).»58

En aquellos días, el colaborador inglés de O Século, James Wexdorf, escribe el 21 de julio que la opinión pública británica es, cada vez, más favorable a los rebeldes: «(...) nos meios financeiros reconhece-se que a ordem reina na Espanha nacionalista e diz-se que os capitais empregados ali teriam o valor de quatrocentos milhoes de libras (...)»(cursiva en el original). ${ }^{59} \mathrm{Y}$ el editorial de $A$ Voz critica la falta de reflejos británicos para entender el «problema» español: «(...) Temos a impressão de que a acção britânica, ou sequer, a opinião publica inglesa, por diversos motivos, e sobretudo, por via da influencia maçonica, poderosissima em Inglaterra, cabia, no concerniente ao conflicto que dilacera a nobre Espanha, em un autêntico «conto do vigario» (...)». ${ }^{60}$ En el Diário de Notícias Vasco Borges es más directo en sus planteamientos:

«(...) O povo inglès é sério e tem consciencia. Tudo está em saberem esclarecer as suas posiçoes os que desejem os seus juizos favoraveis. E nesta hora ele decerto se apercebeu já que Portugal e a Inglaterra nem sempre podem seguir os mesmo caminhos, e, sobretudo, não podem tomar as mesmas providencias em ordem ao fim que ambas as naçoes ambicionam: Salvar a paz da Europa e restituir a gloriosa Espanha á sua alegre tranquilidade doutros tempos. ${ }^{61}$

El proyecto para la retirada de los voluntarios combatientes en ambos bandos, discutido en julio de 1937 en el comité londinense, fue rechazado una vez más por Portugal. Esta vez es Salazar el que comunica a su representante en la comisión

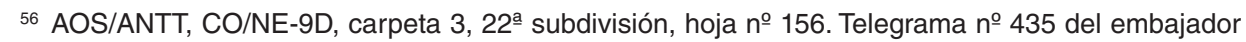
de Portugal en Londres al ministro de Negócios Estrangeiros, 06/07/1937.

57 AOS/ANTT, CO/NE-9D, carpeta 3, 17ª subdivisión, hojas nำ143-144. Telegrama no 130 del embajador de Portugal en Londres al ministro de Negócios Estrangeiros, 04/07/1937.

58 AOS/ANTT, CO/NE-9E, carpeta 3, 17ª̣ subdivisión, hojas nำ 143 y 144 . Telegrama n 130 del embajador de Portugal en Londres al ministro de Negócios Estrangeiros, 04/07/1937.

59 O Século, no 19.880, 21/07/1937, p. 6.

60 A Voz, no $3741,25 / 07 / 1937$, p. 1.

61 Diário de Notícias, no 25.654, 08/07/1937, p. 1. 
internacional las indicaciones del Duque de Alba, que pedía a Portugal no ceder mientras no se le reconociese al general Franco el derecho de beligerancia. Portugal forma un frente diplomático junto con Italia y Alemania para obstaculizar una resolución negativa para el gobierno de Burgos en la reunión del subcomité de no intervención para estudiar el asunto de los voluntarios del 26 de julio. Monteiro mantiene una dura pugna dialéctica con el delegado soviético que le permite proteger los intereses de Franco. ${ }^{62}$

El plan para la retirada de los voluntarios no pudo ser aprobado hasta el 5 de junio de 1938, en un momento en el que la cuestión ya no tenía importancia para ninguno de los dos bandos porque la guerra ya estaba prácticamente decidida. El éxito diplomático del ministerio de Asuntos Exteriores de Portugal, dirigido personalmente por Salazar, fue también objeto de propaganda en la prensa portuguesa. A Voz creía que esta arma ideológica debía ser utilizada con más intensidad para convencer al mundo de las tesis portuguesas con respecto a la Guerra Civil española. «(...) Dispomos, é certo, de um departamento especial de propaganda cuja eficiência, em alguns dos sectores que tem atingido dentro das exigüas dotaçoes que movimenta, está comprovada com largo proveito em espaço de tempo relativamente curto. Quere isto dizer que a nossa engrenagem de propaganda não atingiu aquele conjunto de elementos hoje necessários e imprescindíveis a uma acção internacional de vulto. $E$ as circunstancias criadas em torno do cão espanhol requeriam absolutamente uma acção de tal natureza para auxilio eficaz e justo da política por nós estabelecida (...) (cursiva original)». ${ }^{63}$

\section{LA AYUDA DE PORTUGAL AL FRANQUISMO EN AMÉRICA DURANTE LA GUERRA CIVIL}

El Estado Novo emprendió una ofensiva propagandística internacional que fue más allá de las fronteras europeas. El embajador portugués en Washington destinaba entre 150 y 200 dólares mensuales a hacer contra-propaganda, desmientiendo las informaciones o reportajes que dejaban mal parada la política exterior de su país con respecto a la guerra española. ${ }^{64} \mathrm{El}$ antiguo embajador de España en la capital norteamericana, Juan Francisco Cárdenas, aliado con los rebeldes desde el inicio del pronunciamiento militar, le comunicó el profundo agradecimiento oficial del gobierno de Burgos por el apoyo prestado por Portugal, ya que ellos carecían de fondos suficientes para hacer propaganda en Norteamérica. ${ }^{65}$ El 25

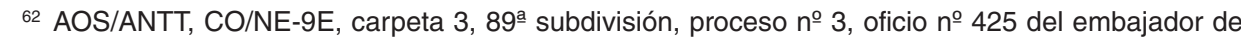
Portugal en Londres a Salazar, 28/07/1937.

63 A Voz, no 3750, 03/08/1937, p. 1.

64 AOS/ANTT, CO/NE-9G, carpeta 1, 1a subdivisión (5), hoja nํㅜ 18. Telegrama no 3 del embajador de Portugal en Washington al ministro de Negócios Estrangeiros, 11/01/1937.

65 AOS/ANTT, CO/NE-9G, carpeta 1, 1a subdivisión (5), hoja ํㅜ 18. Telegrama ํㅡ 3 del embajador de Portugal en Washington al ministro de Negócios Estrangeiros, 11/01/1937. 
de febrero de 1937, el diplomático portugués cuenta en telegrama a Salazar que le respondió al agente rebelde «(...) que temos procurado levar ao conhecimento do Govêrno americano as realidades da situação espanhola e as dificuldades e perigos da nossa posição tal qual o Governo português tem francamente exposto aos outros Govêrnos (...)». ${ }^{66}$ La incondicional actitud de respaldo diplomático de Portugal fue compensado por los agentes rebeldes, que informaban al gobierno luso de las intrigas de los exiliados políticos portugueses en otros países. ${ }^{67} \mathrm{Tal}$ era el grado de compenetración entre ambas diplomacias, la de los rebeldes españoles y la portuguesa, que el representante insurgente en Chile, Tomás Súñer y Ferrer, solicitó del cónsul portugués, el 21 de septiembre de 1938, la utilización de la valija diplomática lusa para hacer llegar la correspondencia oficial al gobierno de Burgos por sospechar que los empleados del correo chileno y francés saboteaban sus cartas. ${ }^{68}$ En América del Sur, las legaciones portuguesas en los diferentes países se pusieron de acuerdo para intentar que los respectivos gobiernos reconociesen el gobierno del general Franco en noviembre de 1936, con especial interés en Brasil, Argentina y Chile. ${ }^{69}$

El gobierno portugués trató de captar el apoyo de las colonias de portugueses en diferentes países del mundo. El Secretariado de Propaganda Nacional (SPN) demostró tener un interés especial por las dos colonias portuguesas más importanes en Europa y América, las de Francia y Brasil. En el país galo se sirvió especialmente de la Casa de Portugal y de la Office de Propagande Commerciale et de Tourisme de I'Etat Portuguais como plataformas de proyección de su propaganda. ${ }^{70}$ Aprovechando las estancias del director del SPN, António Ferro, en Paris para organizar la representación portuguesa en la Exposición Internacional de 1937, realizó algunos actos de propaganda e informó a Salazar de la situación de la comunidad portuguesa en Francia. ${ }^{71}$ En Brasil, donde la colonia portuguesa era muy numerosa, la campaña a favor de la política exterior del Estado Novo fue mu-

66 Ibídem.

67 AOS/ANTT, CO/PC-3G, carpeta 1 («Actividade dos emigrados políticos. Dr. Afonso Costa e Pope, 1937»), hoja 으 51. Telegrama $n \div$ 668. Del Secretario General del Cuartel de Salamanca a Marino Amoedo en Lisboa, 02/05/1937. Entre otros.

${ }_{68}$ AHD/MNE, A 1, M 722, Proceso no 33,2. Oficio no 70 de la Legación de Portugal en Santiago de Chile al Presidente do Conselho, 21709/1938.

69 AOS/ANTT, CO/NE-9B, carpeta 1, 2aㅡ subdivisión, hojas ํㅜ 4-6. Telegrama ํㅡ 30 del embajador de Portugal en Buenos Aires al ministro de Negócios Estrangeiros, 30/11/1936. Véase también: Idem, 4aㅡ subdivisión, telegrama n 69 del embajador de Portugal en Río de Janeiro, Martinho Nobre de Mello, al ministro de Negócios Estrangeiros, 20/11/1936; 10ª subdisivión, telegrama ํㅡ 68 del embajador de Portugal en Río de Janeiro al ministro de Negócios Estrangeiros, 28/1171936; 11ª subdivisión, telegrama n 66 del embajador de Portugal en Río de Janeiro al ministro de Negócios Estrangeiros, 27/11/1936. En este último telegrama Martinho Nobre de Mello comunica a Salazar que podía transmitir al general Franco la buena marcha de las diligencias realizadas entre la embajada portuguesa y el gobierno de Brasil.

70 AOS/ANTT, CO/PC-12A, carpeta 1. «Acção de Propaganda na imprensa estrangeira». (Documentación diversa). Véase también: Clímaco, Cristina, «Portugueses nos campos do Sudoeste de França (1939-41)», in revista Penélope, no 16, Lisboa, 1995, pp. 25-61.

71 AOS/ANTT, CO/PC-3C, carpeta 19, 1a subdivisión, hoja 140. Carta de António Ferro a Oliveira Salazar, 26/10/1936. 
cho más intensa (Paulo, 1994). La repercusión de la propaganda salazarista sobre los emigrantes de esta nacionalidad fue excepcional. En noviembre de 1936, como reacción a la «amenaza marxista» procedente de España contra Salazar, el industrial Raul Monteiro Guimarães, un «bom português» según el Diário da Manhã, lanzó la iniciativa de crear una Legião Portuguesa en Brasil para defender la soberanía portuguesa en Ultramar. ${ }^{72}$ Los periódicos de la colonia portuguesa aplaudieron las decisiones de Salazar en relación al conflicto español y algunos, como $A$ Voz de Portugal, pusieron en marcha una vocinglera campaña de movilización popular a favor de la política exterior de la dictadura salazarista.

El embajador portugués en Rio de Janeiro, Martinho Nobre de Mello, fue objeto de un homenaje por parte de la colonia portuguesa el día 29 de noviembre de 1936 tras una concurrida manifestación que concluyó en la sede diplomática lusa. Además, Nobre de Melo, en un acto oficial en la legación diplomática, leyó un mensaje dirigido por Salazar a la Federação de Associações Portuguesas do Brasil para agradecerle las muestras de apoyo. Tras escuchar las palabras del embajador portugués, intervinieron algunos de los delegados de las asociaciones de la colonia y consejeros de la embajada como Carmelo Lampreia, Raul Monteiro Guimarães y Augusto Sousa Baptista. Este último afirmó que «(...) não há um português no Brasil que, ao lêr as respostas serenas e firmes de Portugal perante a comissão de não-intervenção, se não tenha curvado ante a clarividencia com que o presidente do Conselho português vê as questões internacionais. Quem não há de — preguntou - curvar-se agradecido, diante dêsse homem que numa actividade quase milagrosa enche de progresso a terra portuguesa, escreve páginas gloriosissimas na nossa história e aponta novos rumos á humanidade? (...)». Baptista instó luego a Nobre de Mello a comunicar a su gobierno lo siguiente: «Dizei ao Govêrno português que vivemos contentes na fé da sua obra e no respeito do seu digno representante ${ }^{73}$ Más impresionante fue la organización de una embajada de apoyo a Salazar por parte de la Federação de Associações Portuguesas do Brasil, que llegó a Lisboa el 8 de abril de 1937 para expresar en persona su apoyo a Salazar. ${ }^{74}$ La delegación, a cuya cabeza estaba Vittorio Moreira fue recibida por el general Carmona, el Presidente do Conselho y otras instituciones públicas en un periplo propagandístico que duró 14 días. Durante el viaje institucional de los emigrados, la prensa de la colonia en Brasil y la nacional hicieron una destacada cobertura del acontecimiento. ${ }^{75}$ El Diário da Manhã exalta, el 17 de abril, la existencia de una «solidariedade nacional» de todos los emigrados portugueses esparcidos por los cinco continentes con el Estado Novo en el momento más crítico para el país:

72 Diário da Manhã, no 25.439, 29/11/1936, p. 1.

73 O Século, ํㅜ 19.659, 07/1271936, p. 6.

${ }^{74}$ Anais da Revolução Nacional (1936-1939), Barcelos, Companhia Editora do Minho, vol. 4, s.d., pp. 131 y ss.

${ }_{75}$ O Século, oㅜ 19.784, 15/04/1937, pp. 1 y 2; idem, 19.790, 21/04/1937, pp. 1. Entre otros. 
«(...) A guerra civil de Espanha e as suas possiveis consequências, as complicaçoes provaveis da agitação comunista consentida por alguns governos cómplices de Moscovo, na Europa e fora da Europa, as lutas de influência e de prestígio entre as grandes potências, que justificam a corrida louca ãos armamentos, a falência de instituiçoes democráticas como a SDN, criaram, no Mundo, um ambiente moral de incerteza e de expectativas trágicas que nos levam prudentemente a preparar a Nação para as piores eventualidades. E por isso que «hoje mais que nunca, Portugal conta com todos os seus filhos" (frase de Oliveira Salazar), cujo patriotismo desperto levantará por toda a parte o movimento de solidariedade nacional em face do perigo. Neste sentido, o exemplo dos portugueses do Brasil é proveiotoso e ficará memorável. Foi dado na hora própria e com nobreza e dignidade só comparáveis os da política que o inspirou.» 76

La solidaridad con el Estado Novo en aquellos momentos trascendentes provino también de la Junta Oficial Nacionalista de Río de Janeiro, que felicitó por telegrama al dictador portugués el 26 de octubre de 1936 cuando éste decidió cortar las relaciones con la IIㅍ República. «Españoles nacionalistas del Brasil presentan con honda emoción y vibrante entusiasmo gesto altivo sereno gobierno glorioso Portugal rompiendo relaciones dirigentes marxistas Madrid. Stop. Rogamos aceptar felicitaciones calurosas extensivas autoridades país hermano». ${ }^{77}$

\section{LA INSTAURACIÓN DEL FRANQUISMO Y EL CAMBIO DE CICLO EN LAS RELACIONES IBÉRICAS}

El relato histórico sobre las relaciones ibéricas en el período que va desde el fin de la Guerra Civil hasta la victoria aliada en la conflagración mundial ha sido analizado de manera especializada por autores como Juan Carlos Jiménez Redondo ${ }^{78}$ o Manuel Loff, ${ }^{79}$ entre otros, que han elaborado una radiografía muy completa sobre el comportamiento político y la estrategia diplomática de ambas dictaduras durante este período histórico. En general, la visión que aquí se aporta sobre la evolución de las relaciones ibéricas en este nuevo contexto, dentro del determinante panorama internacional del momento, es coincidente con el punto de vista de los investigadores citados.

\footnotetext{
76 Diário da Manhã, no 2151, 17/04/1937, p. 1.

77 AOS/ANTT, CO/NE-9I, carpeta 1, carpeta 2, 15ª subdivisión, hoja ํㅜ 53. Telegrama ํo 77148 de la Junta Oficial Nacionalista de Río de Janeiro a Salazar, 26/10/1936.

78 JIMÉNEZ REDONDO, Juan Carlos: «Bases teórico-políticas del bloque ibérico: la relación peninsular en la fase de inflexión de la II Guerra Mundial, 1942-1945», in Espacio, Tiempo y Forma. Serie V: Historia Contemporánea, 7, pp. 181-204; idem, «La política del bloque ibérico: las relaciones hispano-portuguesas (1936-1949)", in Mélanges de la Casa Velazquez. Tomo 29-3, 1993, pp. 175-201; idem, «El papel de Nicolás Franco en la conducción de la política española hacia Portugal», in Historia Contemporánea, 15, 196, pp. 179-191.

79 LOFF, Manuel, O Nosso Século é Fascista. O Mundo visto por Salazar e Franco (1936-1945), Porto, Campo das Letras, 2008; idem, Salazarismo e Franquismo da Época de Hitler. Convergência Política, Preconceito Ideológico e oportunidade histórica na redefinição internacional de Portugal e Espanha (1936-1942), Porto, Campo das Letras, 1996.
} 
Tanto la Guerra Civil española como la posterior Segunda Guerra Mundial alteraron la estrategia política exterior de Portugal, que tradicionalmente prefería vivir de espaldas a Europa, con una marcada vocación atlantista. Su proyección internacional estaba definida por su papel de potencia colonial en África y Asia, cuya condición imperial alimentaban un sentimiento de orgullo patriótico y una sensación de poder e influencia internacional. ${ }^{80}$ Ser un imperio y revindicar una posición imperial frente a la histórica posición dominante de España en el marco de unas relaciones ibéricas en las que Portugal se sentía vulnerable debido a la atávica percepción del «perigo espanhol», era no sólo una cuestión de estrategia política en el escenario internacional, de la necesidad de mostrar a los vecinos su poderío a través de la amplia extensión de sus territorios ultramarinos; era también una cuestión de identidad nacional, de la definición de la idea de Portugal como nación y, por tanto, una cuestión de imagen: cómo el Estado Novo quería representarse a sí mismo y a la sociedad portuguesa ante el mundo. El famoso eslogan de la propaganda imperialista portuguesa a principios de los años cuarenta que proclamaba que «Portugal não é um País Pequeno» invitaba a los portugueses justamente a creer en su condición de país imperial. Por tanto, para Salazar el imperio era, probablemente, la mejor manera de amplificar su poder en el tablero diplomático internacional, pero también de reafirmar su liderazgo peninsular frente a una España que había perdido todas sus posesiones coloniales.

Sin embargo, el decisivo apoyo que la dictadura portuguesa prestó al Movimiento Nacional franquista para su victoria en la Guerra Civil, como se ha podido leer en los epígrafes precedentes, modificó ese posicionamiento estratégico atlantista ligado a su histórica alianza con Gran Bretaña y a sus intereses coloniales. Esto introdujo «(...) un factor de profunda contradicción entre la ubicación del país dentro de la problemática de ruptura y reconstrucción europea propiciada por la guerra y el radical rechazo ideológico-dogmático del salazarismo a aceptar esta continentalidad, privilegiando no sólo en su discurso sino también en su acción, su decidida acción imperial,» según la apreciación del profesor Jiménez Redondo. ${ }^{81}$ Esta circunstancia condujo a un cierto despegue de la relación secular con Gran Bretaña, pero con la prudencia necesaria como para no arriesgar la seguridad y estabilidad que proporcionaba la Alianza Luso-Británica. ${ }^{82}$ Los intereses de ambos aliados, no obstante, acabaron por coincidir en 1939 en el objetivo fundamental de mantener la Península Ibérica ajena al conflicto europeo que se avecinaba. Esta política de neutralización anglo-portuguesa acabó convergiendo también con los deseos del gobierno de Burgos de apartarse del nuevo escenario bélico europeo y

80 Cf.: TORRE GÓMEZ, Hipólito de la (coord.), Portugal, España y África en los últimos cien años, Mérida, Uned, 1992.

81 JIMÉNENEZ REDONDO, Juan Carlos, «Bases teórico-políticas...», art. cit., p. 184.

82 ROSAS, Fernando, «A Guerra Civil de Espanha e a aliança luso-británica», in História, 71, Lisboa, 1984, pp. 23-38. 
prevenir una eventual invasión británica de la Península. ${ }^{83}$ Así nació el Tratado de Amistad y No Agresión del 17 de marzo de 1939. Su contenido era lo suficientemente ambigüo como para no alterar en lo sustancial los derechos y deberes de la Alianza Luso-Británica, y lo cuidadosamente preciso para garantizar la inviolabilidad de las fronteras entre España y Portugal. ${ }^{84}$ Aunque el gobierno franquista intentó alejar a Portugal de su alianza con Inglaterra, Salazar no estaba dispuesto a renunciar a la seguridad que brindaba la alianza frente a un vecino al que veía con desconfianza. La victoria militar en la Guerra Civil agitó las veleidades imperialistas de un sector de la Falange Española, cuya delegación y afiliados en Lisboa fueron sometidos a estricta vigilancia de la Policía de Defesa e Vigilância do Estado (PVDE), ante el temor a que pudieran extender su influencia en Portugal. Además, Salazar se sentía inquieto porque había descubierto que la tesis de graduación de Franco en la Academia de Cadetes de Toledo se titulaba "Cómo invadir Portugal en 28 días». ${ }^{85}$ Por tanto, aunque el conflicto español ayudó a consolidar su proyecto político en Portugal y su desenlace fue decisivo para su prolongación en el tiempo, Salazar volvía a reencontrarse nuevamente con el «perigo espanhol». Si la II República era un régimen nocivo para los intereses del Estado Novo por inspirarse en un modelo ideológico antagónico y representar un proyecto político en el que el federalismo y el iberismo revolucionario formaban parte del debate político, el movimiento franquista contenía elementos todavía más radicales que expresaban nostálgicos deseos imperiales basados en la unidad ibérica... ${ }^{86}$

En este contexto, la política exterior española osciló entre el irrefrenable deseo de aproximarse e incluso aliarse con Alemania e Italia y la cautela necesaria para sobrevivir en un proceloso escenario diplomático europeo, en el que España se encontraba en una encrucijada. Obviamente, su vinculación con Hitler y Mussolin se debía tanto a la afinidad ideológica de sus regímenes y al deslumbramiento que sentía Franco por ellos, como a la gratitud debida por la apoyo militar en la guerra española. ${ }^{87}$ Pero lo que quizás más determinó la orientación de la estrategia política del franquismo fue el hecho de que Alemania no atendiese sus ambiciones territoriales sobre el Norte de África y la situación de dependencia de los suministros controlados por Gran Bretaña a los que España, sometida a una situa-

${ }^{83}$ Cf.: MORADIELLOS, E., Neutralidad benévola. El gobierno británico y la insurrección militar española de 1936, Oviedo, Editorial Pentalfa, 1990.

84 GÓMEZ DE LAS HERAS HERNÁNDEZ, María Soledad, «España y Portugal ante la Segunda Guerra Mundial desde 1939 a 1942», in Espacio, Tiempo y Forma. Serie V: Historia Contemporánea, 7, 1994, pp. 165-179.

85 PENA RODRÍGUEZ, Alberto, Galicia, Franco y Salazar..., Op. Cit., pp. 82-92

86 Cf. AREILZA, J. M., CASTIELLA, F. M., Reivindicaciones de España. Madrid, Instituto de Estudios Políticos, 1941; SEMINARIO, Álvaro, España y Portugal: incitaciones a una política de acercamiento espiritual, Madrid, Espasa-Calpe, 1940.

87 Cf. RUHL, K. J., Franco, Falange y III Reich. España durante la II Guerra Mundial, Madrid, Akal, 1986; TUSELL, J. \& G. QUEIPO DE LLANO, Franco y Mussolini. La política española durante la II Guerra Mundial, Barcelona, Planeta, 1985. 
ción económica paupérrima, no podía renunciar. ${ }^{88}$ El pragmatismo diplomático imperó entonces en las decisiones del gobierno franquista, que impulsó la firma del Primer Protocolo Adicional al Tratado de Amistad y No Agresión del 29 de julio de 1940. ${ }^{89}$ Aunque España parecía querer intervenir en la guerra al lado de Hitler, sobre todo después de la muestra de poderío militar alemán con la invasión de Francia, Franco fue lo bastante precavido como para intentar, a través del nuevo acuerdo, garantizar prioritariamente que Portugal no permitiera la presencia de tropas británicas en su territorio y, en cierto modo, que la política de Lisboa se sometiera a los intereses de Madrid. Sin embargo, el gobierno salazarista no cedió a las presiones del germanófilo Serrano Súñer para que Portugal abandonara su alianza con Inglaterra y consiguió que el gobierno español refrenara en cierta medida sus deseos intervencionistas manteniendo el status quo ibérico. ${ }^{90}$

La entrevista entre Franco y Hitler en Hendaya en octubre de 1940 fue el momento de máxima aproximación de España a las potencias de Eje, adquiriendo la condición de potencia no beligerante. Pero la situación de dependencia económica española de los británicos y la falta de atención a las reivindicaciones territoriales franquistas alejaron poco a poco a la España franquista de sus tentaciones belicistas. No obstante, durante 1941 el recelo se instaló en las relaciones luso-españolas debido, entre otras razones, a la permanencia de Serrano Súñer en el gobierno como ministro de Asuntos Exteriores hasta septiembre de 1942. En febrero de ese mismo año se produjo en Sevilla el encuentro entre Franco y Salazar, que se reunieron para tratar de solucionar varios asuntos relacionados con la estrategia política de ambos países ibéricos en el panorama europeo. ${ }^{91} \mathrm{~A}$ Salazar le preocupaban las presiones alemanas sobre España, que Franco negó, y Franco expresó su temor a un eventual desembarco de tropas británicas en las islas atlánticas, que Salazar descartó. ${ }^{92}$ También hablaron de la necesidad de coordinar una política conjunta hacia Iberioamérica para contrarrestar la influencia de Estados Unidos, como de hecho así hicieron con resultados negativos en sus respectivas relaciones con los diferentes países iberoamericanos. ${ }^{93}$

\footnotetext{
${ }^{88}$ Cf. VIÑAS, Ángel, Guerra, dinero y dictadura. Ayuda fascista y autarquía en la España de Franco, Barcelona, Crítica, 1984.

${ }^{89}$ AMAE. L 3372, Exp. 22. I Protocolo Adicional al Tratado de Amistad y No Agresión entre España y Portugal. Lisboa, 29 de julio de 1940.

90 Cf. Comissão para o Livro Negro sobre o Regime Fascista, Correspondência de Pedro Teotónio Pereira para Oliveira Salazar, 4 vols., Lisboa, 1987-1991.

91 REZOLA, Maria Inácia, «The Franco-Salazar Meetings: Foreign policy and Iberian relations during the Dictatorships (1942-1963)", in E-Journal of Portuguese History, vol. 6, 2, 2008, pp. 2-11.

92 JIMÉNEZ REDONDO, Juan Carlos, «Bases teórico-políticas...», art. cit. pp. 189-190.

93 TELO, Antonio José, Portugal en la Segunda Guerra Mundial, Lisboa, Editora Vega, 1996, vol I, pp. 79 y ss.
} 


\section{LA CREACIÓN DEL BLOQUE IBÉRICO Y LA SEGUNDA GUERRA MUNDIAL}

El 16 de diciembre de 1942, el viaje a Lisboa del ministro de Asuntos Exteriores español, Conde de Jordana, impulsa un nuevo rumbo de las relaciones peninsulares con la proclamación del Bloque Ibérico. ${ }^{94}$ La situación propiciada por la Segunda Guerra Mundial, en la que las dictaduras ibéricas se encontraban atrapadas entre los dos bandos compartiendo unos presupuestos ideológicos y un deseo de supervivencia política común, obligó a ambos gobiernos a encontrar nuevas vías de diálogo y espacios de entendimiento. Era perentorio para ambos regímenes lograr el equilibro necesario para proteger y defender su proyecto político dentro de un panorama internacional inestable, inseguro y que podría incluso ser muy adverso si no sabían transmitir a ambos bloques en lucha un mensaje claro, articulado dentro de una campaña de propaganda adecuada a sus intereses. Era, evidentemente, una estrategia de carácter defensivo para evitar, sobre todo, que los cambios políticos que pudieran ocurrir en el contexto europeo no les afectaran directamente, en particular en el caso de una victoria soviética sobre Alemania y la peligrosa influencia que representaría para ambos gobiernos un movimiento comunista fuerte en Europa. ${ }^{95}$

La entrevista del Conde Jordana y Salazar en Lisboa giró justamente acerca de la necesidad de fijar un frente común contra en avance del comunismo, que según ellos era el origen del antagonismo anglo-germánico, y que amenazaba con destruir la civilización cristiana occidental. Ambos convinieron que el triunfo británico y soviético podría significar el inicio de un proceso revolucionario que se extendería por toda Europa, ante el que era imprescindible aliarse. ${ }^{96}$ Según Jiménez Redondo, el gobierno español tenía, sobre todo, una intencionalidad propagandística, «(...) para resaltar que su mantenimiento al margen de la guerra respondía a una orientación política permanente, intentando un cierto desmarque en un momento donde los aliados empezaban a alcanzar posiciones de ventaja en el transcurso del conflicto bélico". ${ }^{97} \mathrm{Al}$ mismo tiempo, los mensajes de propaganda de ambas dictaduras intentaban transmitir la idea de que ambos regímenes eran producto de dinámicas políticas internas; que eran ajenos a las estrategias militares de los principales actores en la conflagración mundial; que eran radicalmente anticomunistas; y que su filiación ideológica era profundamente cristiana y católica. ${ }^{98}$ Ambos gobiernos ibé-

94 TUSELL, J., «Un giro fundamental en la política española durante la II Guerra Mundial. La llegada de Jordana al Ministerio de Asuntos Exteriores», en J. L. GARCÍA DELGADO (ed.), El primer franquismo. España durante la I/ Guerra Mundial, Madrid, Siglo XXI, 1989, pp. 275-307.

95 SACRISTÁN, E., «Relaciones peninsulares durante la II Guerra Mundial», in Proserpina, 1, 1984, pp. 145-159.

96 AMAE, L 1375, Exp. 16. Borrador de temas de conversación del Sr. Ministro de Asuntos Exteriores con el presidente de la República portuguesa y con el Dr. Oliveira Salazar. 16 de diciembre de 1942. Citado por Juan Carlos Jiménez Redondo en «Bases teórico-políticas...», p. 193.

97 Ibídem.

98 Documentos sobre el Bloque Ibérico, Madrid, Ministerio de Asuntos Exteriores, 1942. 
ricos estaban, además, convencidos de que la estabilidad política en la Península Ibérica sólo sería posible con el mantenimiento de una acción conjunta exterior para enfrentar a los enemigos comunes. Era un pacto implícito que unía a los dos países en su búsqueda de la supervivencia, más allá del desenlace final de la Segunda Guerra Mundial.

La acción exterior conjunta retoma otra vez los momentos vividos durante la Guerra Civil, en los que la diplomacia salazarista y franquista actuaron de forma coordinada para defender internacionalmente sus intereses frente al gobierno de la II República, como se ha descrito más atrás. De todas formas, el recelo portugués al iberismo latente en la España franquista todavía se manifiesta en algunos aspectos relacionados sobre todo con la construcción de la retórica propagandística del acuerdo tácito del Bloque Ibérico. El gobierno luso solicita, por ejemplo, que se utilice la expresión "Bloque Peninsular» para alejar cualquier posible confusión entre el auténtico significado del acuerdo, de sentido estratégico y oportunidad política, y el movimiento iberista. ${ }^{99} \mathrm{La}$ indiscutible separación entre los dos Estados debía estar perfectamente clara cuando se invocara o se pusiera en práctica cualquier tipo de medida que afectara al Bloque en el escenario internacional.

Es incuestionable, por tanto, que la creación del Bloque Ibérico (o Peninsular), que supone uno de los momentos de mayor acercamiento político entre los dos países a lo largo de su Historia, sólo es posible por dos razones esenciales: por el temor a una intervención extranjera en la Península y por el debilitamiento de la desconfianza portuguesa hacia el «peligro español». Esta nueva etapa será muy relevante para definir un nuevo contexto en las relaciones diplomáticas ibéricas, que irán evolucionando hacia posicionamientos políticos menos antagónicos. ${ }^{100}$ Las prevenciones y desconfianzas portuguesas frente a España seguirán presentes, aunque tamizando ciertas posibilidades de un mayor estrechamiento peninsular. La relación peninsular acabará por resultar contradictoria, pero al mismo tiempo lo suficientemente pragmática como para convertir a las dictaduras ibéricas en regímenes capaces de convivir separados y transformar el espacio común de convivencia inalterable a los acontecimientos internacionales ${ }^{101}$. En este nuevo contexto, la propaganda del franquismo experimenta una clara evolución hacia presupuestos teóricos más respetuosos con Portugal, dejando de lado las proclamas paternalistas e iberistas y adaptando las viejas ideas imperialistas dentro de una doctrina de unidad cultural y espiritual en el orbe hispanoamericano. ${ }^{102}$

99 Cf.: PORTUGAL. Boletim do Secretariado Nacional de Informação, Lisboa, 1942.

100 ROSAS, Fernando, "O Pacto Ibérico e a neutralização da Península», in História, 57, 1983, pp. 2-17.

101 Cf.: TORRE GÓMEZ, Hipólito de la (coord.), Portugal, España y América. Pasado y presente de un proyecto (s. XIX y XX). Homenaje a la Profesora Pilar Vázquez Cuesta, Mérida, V Jornadas de Estudios Luso-Españoles, Uned, 1993; idem, Portugal, España y Europa (1890-1990). III Jornadas Luso-Españolas. Mérida, Uned, 1991.

102 BARBEITO DÍEZ, Mercedes, «El Consejo de la Hispanidad», en Espacio, Tiempo y Forma. Historia Contemporánea. Serie V, 1989, pp. 113-141. 
El destino de Portugal estaba unido al destino e España y viceversa. Por tanto, ambos países había llegado al convencimiento de que se necesitaban mutuamente, de que no había otro camino para sobrevivir que mantenerse unidos frente a los cambios que, inevitablemente, acarrearía la guerra. ${ }^{103}$ Aún así, ambos gobiernos adoptaron una actitud distante durante los últimos años del conflicto, colaborando únicamente en aspectos relacionados con el combate a los movimientos políticos clandestinos. ${ }^{104}$ Aunque Salazar era consciente de que el Estado Novo portugués tenía una mejor imagen internacional que el franquismo porque había sido una régimen creado sin una sangrienta guerra como en España y porque su estrategia propagandística representaba una dictadura amable (dirigida por un profesor universitario de profundas convicciones católicas) que había restaurado el país, también intuía que sería muy difícil consolidar su modelo político si España no estaba en sintonía política con Portugal.

Al final de la guerra, Portugal volvió a asumir la defensa internacional de los intereses franquistas, realizando campañas de propaganda que presentaban al Bloque Ibérico como un territorio neutral que armonizaba con los intereses anglosajones. ${ }^{105}$ El aislamiento internacional del franquismo se institucionalizó en marzo de 1945, durante la celebración de la primera Comisión de la Conferencia de las Naciones Unidas, cuando formalmente se le negó la entrada la ONU (por tratarse de un régimen creado con la ayuda Alemania e Italia) y durante la Conferencia de Potsdam, que convirtió a Franco en un líder político proscrito. ${ }^{106}$ En este contexto, una vez más, Franco encontró en Portugal el aliado que necesitaba para intentar mejorar las relaciones con Gran Bretaña dentro del nuevo escenario político internacional.

\section{CONCLUSIONES}

El Estado Novo salazarista fue uno de los actores políticos internacionales que más intervinieron en la Guerra Civil española a favor del bando franquista. Su apoyo al gobierno de Burgos resultó determinante en la gestión diplomática y propagandística de los intereses políticos y la imagen de Franco en el exterior, en particular durante el desarrollo del Pacto de No Intervención (firmado por 27 países europeos), que pretendía evitar la injerencia extranjera en el conflicto español. Sin embargo, Portugal, alegando un problema de soberanía nacional, se negó a que sus fronteras fueran fiscalizadas por el Comité de Londres, para poder seguir enviando armas y combatientes al bando franquista desde su propio territorio,

${ }^{103}$ VICENTE, Ana, Portugal visto pela Espanha, Lisboa, Assirio \& Alvim, 1992.

104 JIMÉNEZ REDONDO, Juan Carlos, «La política del bloque ibérico: las relaciones hispano-portueguesas (1936-1949)», art. cit., p. 191; idem, «Bases teórico-políticas...», art. cit., pp. 198-199.

105 SALAZAR, António de Oliveira, Portugal y la Paz, Lisboa, Secretariado Nacional de Informação, 1945.

106 PORTERO, Florentino, Franco aislado. La cuestión española, Madrid, Aguilar/Maior, 1989. 
convertido durante toda la guerra en retaguardia de los militares sublevados y en un eficaz aliado para la legitimación exterior del franquismo.

Los medios diplomáticos del gobierno y la prensa portuguesa, coordinados con las autoridades franquistas, realizaron una intensa campaña internacional contra los países y los medios de comunicación que criticaron su posición contraria a los trabajos del comité londinense en la Península. Por medio de comunicados oficiales emitidos por el propio Salazar, de entrevistas periodísticas a medios internacionales de sus diplomáticos y del pago a periodistas extranjeros para la publicación de artículos favorables a su posición política en medios de comunicación influyentes, la dictadura portuguesa logró un relevante protagonismo en el escenario internacional en la defensa de los intereses de Franco, que contó de este modo con una excelente plataforma propagandística para promocionar su modelo político tanto en Europa como en América.

Durante la Segunda Guerra Mundial, los cambios geo-políticos producidos en el escenario europeo debido a la estrategia de alianzas entre uno y otro bando en combate, amenazaron la estabilidad de las relaciones ibéricas. En un primer momento, ambos gobiernos sintieron la necesidad de garantizar la soberanía y neutralidad peninsular frente a cualquier posible injerencia con la firma del Tratado de Amistad y No Agresión en marzo de 1939. Con Franco más cerca de las potencias del Eje después de la invasión triunfal nazi de Francia y del cambio de posición política de España en el conflicto (que cambió su neutralidad por la no beligerancia), el pacto debió ser ampliado posteriormente con el Protocolo Adicional de julio de 1940 debido a los temores españoles a un desembarco de tropas británicas en la Península. Los atávicos recelos hacia el «perigo espanhol» (ahora alimentado por el discurso imperialista e iberista del falangismo) y la gestión de las relaciones exteriores por un filo-nazi como Serrano Súñer, entre otros factores, congelaron las relaciones hispano-portuguesas durante 1941, hasta que el nombramiento del Conde de Jordana como nuevo ministro de Asuntos Exteriores las revitalizó.

En esta nueva etapa, se produjo el histórico encuentro sevillano de Franco y Salazar en febrero de 1942. Y meses después fructificaría el Bloque Ibérico, que pretendía funcionar como escudo y antídoto frente a las mudanzas que pudieran surgir en el tablero diplomático europeo después del fin de la guerra. Los dos regímenes establecían una alianza ideológica basada en su doctrina anti-comunista y católica en la defensa de la civilización cristiana occidental. Su objetivo propagandístico era transmitir al mundo la idea de que los dos regímenes, manteniendo su soberanía intacta, formaban parte de un proyecto político común que garantizaba la plena neutralidad de ambos países ante el nuevo orden internacional. Por tanto, Salazar y Franco sellaban así un pacto tácito de respeto recíproco por la independencia doméstica del otro, actuando a nivel internacional como hermanos siameses para lograr desarrollar sus respectivos proyectos políticos autoritarios frente a cualquier influencia externa. 
